\title{
Novel Sources of Resistance to Root-Lesion Nematode (Pratylenchus thornei) in a New Collection of Wild Cicer Species (C. reticulatum and C. echinospermum) to Improve Resistance in Cultivated Chickpea (C. arietinum)
}

\author{
Roslyn A. Reen, ${ }^{1, \dagger}$ Michael H. Mumford, ${ }^{2}$ and John P. Thompson ${ }^{1}$ \\ ${ }^{1}$ Centre for Crop Health, University of Southern Queensland, Toowoomba, 4350, QLD, Australia \\ ${ }^{2}$ Department of Agriculture and Fisheries, Leslie Research Facility, Toowoomba, 4350, QLD Australia \\ Accepted for publication 18 March 2019.
}

\begin{abstract}
Pratylenchus thornei, a nematode species that feeds and reproduces in chickpea (Cicer arietinum) roots, is widespread throughout the Mediterranean basin and Indian subcontinent. In Australia, it can cause yield losses up to approximately $25 \%$ of intolerant chickpea cultivars. Potential for improvement has been hindered by the narrow genetic diversity of cultivated chickpea and a limited world collection of original wild Cicer spp. in the primary gene pool, consisting of 18 C. reticulatum and 10 C. echinospermum accessions. Recently, collections of $C$. reticulatum and $C$. echinospermum from Turkey have substantially increased the number of accessions. This study evaluated 133 C. reticulatum and 41 C. echinospermum accessions from the new collection for resistance to $P$. thornei under controlled conditions in repeated glasshouse pot experiments. The aim of the study was to identify accessions with resistance superior to that currently available in Australian germplasm. Both wild Cicer spp. were found, on average, to be more resistant to $P$. thornei $(P<0.001)$ than $C$. arietinum. Combined analyses across experiments to determine genetic rankings
\end{abstract}

ABSTRACT showed that $13(7 \%)$ wild accessions were significantly more resistant than the most resistant $C$. echinospermum reference ILWC 246, while another $40(23 \%)$ accessions were significantly more resistant than the least susceptible Australian chickpea cultivar PBA Seamer. Mean P. thornei population densities differed significantly between collection sites in Turkey and within each of the genetic population groups. The sites Kayatepe and Baristepe1, and genetic population groups Ret_A and Ret_F associated with sites Oyali and Baristepe1, produced the lowest $P$. thornei population densities. This is the first report assessing the resistance to $P$. thornei of this new collection which offers novel sources of $P$. thornei resistance and untapped genetic diversity valuable for international chickpea breeding programs to exploit.

Keywords: disease control and pest management, genetics and resistance, nematology, root biomass, root-lesion nematode, wheat Triticum aestivum, wild chickpea
In the past decade, there has been a major focus in agriculture worldwide oriented toward increased pulse production. Pulses such as chickpea (Cicer arietinum) supply starch, protein, and cholesterol-lowering dietary fiber (Perez-Hidalgo et al. 1997). Chickpea belong to the small group of crop species $(<20)$ that feed the world population today (Smýkal et al. 2018). Over $95 \%$ of chickpea production occurs in developing countries, where it has an important role in improving food security and reducing malnutrition (Kozgar 2014). Global demand has rapidly increased since 2004, resulting in valuable exports from developed countries such as Australia, where the export value of chickpea in 2017 was approximately 2 billion Australian dollars (ABARES 2017; Chauhan et al. 2017). Currently, India is the largest producer and Australia ranks as the world's largest exporter of chickpea (FAOSTAT 2017; Pulse Australia 2016).

Over $90 \%$ of chickpea production in Australia is within the subtropical, semiarid grain region in the northeast of the country

\section{${ }^{\dagger}$ Corresponding author: R. A. Reen; Roslyn.reen@usq.edu.au}

Funding: We thank the Grains Research and Development Corporation for funding this research through Project USQ00017 and Queensland Department of Agriculture and Fisheries for support under the Broad-acre Cropping Initiative with University of Southern Queensland.

*The $\boldsymbol{e}$-Xtra logo stands for "electronic extra" and indicates that two supplementary tables are published online.

The author(s) declare no conflict of interest.

(C) 2019 The American Phytopathological Society
(Chauhan et al. 2017). In this region, chickpea also plays a beneficial role as a rotational crop in cereal-dominated systems by fixing nitrogen $(\mathrm{N})$ and reducing the incidence of Fusarium pseudograminearum (crown rot) (Dalal et al. 1998; Felton et al. 1998). Counteracting these rotational benefits is the presence of the rootlesion nematode (Pratylenchus thornei), a migratory endoparasite that feeds and reproduces in the roots of cereals and pulses, destroying cortical cells (Fortuner 1977). Globally, the negative impact on chickpea production by root-lesion nematodes (Pratylenchus spp.) ranks second to root-knot nematode (Meloidogyne spp.), particularly in the Mediterranean basin and Indian subcontinent, where $P$. thornei is a major constraint to legume and cereal production (CarrascoBallesteros et al. 2007; Castillo et al. 1998a, 2008). P. thornei is also the most common plant-parasitic nematode species within the subtropical grain region of Australia (Thompson et al. 1999, 2010). Where chickpea is often grown in rotation with wheat (Triticum aestivum), yield losses of up to 25 and $50 \%$, respectively, in intolerant cultivars have been attributed to P. thornei (Reen et al. 2014; Thompson et al. 2000). To date, there is no published evidence of information regarding totally resistant chickpea or wheat cultivars and current management relies on growing tolerant cultivars and rotation with resistant crops. Growing several resistant crops in a cropping sequence or maintaining weed-free fallow over approximately 3 years is necessary to effectively reduce $P$. thornei populations in the soil to below the damage threshold of 2,000 nematodes $/ \mathrm{kg}$ of soil (Owen et al. 2014; Reen et al. 2014; Thompson et al. 2010, 2017; Whish et al. 2017). Incorporating genetic resistance through plant breeding into cultivars of susceptible crop species is the most effective and economical way to manage the overall problem by reducing the high 
population densities of $P$. thornei remaining in the soil after growing susceptible crops.

Resistance and tolerance to nematodes of crop cultivars are considered independent genetic traits (France and Brodie 1996). Resistance is the ability of a plant to reduce nematode reproduction (Trudgill 1991) and tolerance is the capacity of the plant to yield well in nematode-infested soil (Cook and Evans 1987). Current breeding efforts struggle to produce disease-resistant chickpea cultivars that will extensively increase production (Singh et al. 2015) owing to the narrowing of genetic diversity of traits resulting from domestication and a series of selective constraints during the evolution of the crop (Abbo et al. 2003; Ladizinsky and Adler 1976; Rao et al. 2007; Varshney et al. 2013). In contrast, multiple studies have shown that wild Cicer spp. offer superior sources of genetic resistance and diversity, making them a valuable resource for chickpea improvement (Abbo et al. 2003; Andeden et al. 2013; Muñoz et al. 2017; Rao et al. 2007; Sudupak et al. 2002; Toker et al. 2007). Interspecific hybridization of wild annual Cicer spp. has the potential to widen the genetic base of cultivated chickpea without penalty to yield or adaptation (Koseoglu et al. 2017; Singh and Ocampo 1997; Singh et al. 2015; Singh et al. 2005).

The annual species $C$. reticulatum and C. echinospermum in the primary gene pool of chickpea are the only crop wild relatives (CWR) cross-compatible with domestic chickpea (Croser et al. 2003). Both species occur only in a restricted area of southeastern Anatolia (Turkey) within rocky slopes, open forests, orchards, vineyards, and fields (Ballard et al. 2006; Tanno and Willcox 2006). Both species are currently under threat from urbanization, climate change, grazing, and industrial development (Talip et al. 2018; Von Wettberg et al. 2018). In early research, resistance to $P$. thornei was found in Cicer spp. from the secondary gene pool (C. bijugum, and $C$. judaicum) and tertiary gene pool (C. cuneatum and $C$. yamashitae) but not in C. reticulatum or C. echinopsermum (Di Vito et al. 1995). In subsequent research, resistance to $P$. thorne $i$ was identified in some accessions of $C$. reticulatum and $C$. echinospermum, resulting in incremental gains for resistant chickpea (Rodda et al. 2016; Thompson et al. 2011). However, at that time, the genetic diversity in wild germplasm held in seed gene-bank collections was compromised due to a limited world collection that consisted of only 18 original C. reticulatum and 10 C. echinospermum accessions (Abbo et al. 2003).

Recently (2013 to 2015), new collection missions in southeastern Turkey that spanned both the genomic diversity and environmental range of the wild progenitor species $C$. reticulatum (Ladizinsky and Adler 1976) resulted in numbers of accessions of $C$. reticulatum and C. echinospermum increasing 21-fold and 9-fold, respectively (Von Wettberg et al. 2018). A study of the genetic variation in this collection through genotyping-by-sequencing and analysis in the program STRUCTURE identified four different genetic population groups of C. echinospermum and eight of C. reticulatum (Von Wettberg et al. 2018). These genetic populations formed a cline largely related to the location of collection sites in an east-west transect through southeast Anatolia. To understand the consequences of domestication, whole-genome sequencing was performed on 26 diverse wild accessions. From these studies, it was concluded that 94 to $98 \%$ of the progenitor genetic variation in this CWR collection is currently lacking in breeding programs of the cultigen $C$. arietinum. The 26 diverse wild accessions were chosen for construction of introgression populations, with seven international elite $C$. arietinum cultivars representing major global climatic chickpea production zones (Von Wettberg et al. 2018).

Characterizing this new, more extensive collection of chickpea wild relatives for $P$. thornei resistance will enable selection of germplasm that will potentially widen the genetic base for resistance and the adaptive diversity of chickpea. Growing chickpea cultivars with a high level of resistance will result in reduced nematode populations in the soil that will allow diversified rotational options and more economical yields for growers. The purpose of this research was to (i) characterize individual accessions in this new, wider collection of chickpea wild relatives for resistance to $P$. thornei, in comparison with a selection of Australian chickpea cultivars; (ii) compare the level of resistance within the two wild species $C$. reticulatum and $C$. echinospermum with the cultivated species $C$. arietinum; (iii) assess the effect of geographic location on level of resistance in the CWR; and (iv) assess the effect of genetic population groups on level of resistance in the CWR.

\section{MATERIALS AND METHODS}

Plant phenotyping. Two experiments were conducted during the winter to spring season in Australia (July to November) in 2016 (experiment 1) and 2017 (experiment 2) to assess the resistance to $P$. thornei of 174 annual wild Cicer accessions collected from Turkey in 2013. Accessions obtained from the Australian Grains Genebank consisted of 133 C. reticulatum and 41 C. echinospermum collected from 21 sites within five provinces of southeastern Turkey. The number of accessions collected within each site varied from 1 to 17 . Each site and province had only C. reticulatum or C. echinospermum present, with the exception of the province Diyarbakir, where both species were collected (Table 1). In all, 22 reference cultivars that ranged in levels of $P$. thornei resistance and 1 inoculated unplanted control treatment were included in the experiments. The reference cultivars included 11 Australian desi chickpea cultivars that were moderately susceptible (PBA Boundary, PBA HatTrick, PBA Seamer, PBA Pistol, Flipper, Howzat, and Yorker), susceptible (Jimbour, Sona, and Sonali), and very susceptible (Kyabra) (GRDC 2019). One desi cultivar found to be resistant in India (ICC11323) and one moderately resistant $C$. reticulatum derivative (00283-1095-1002 from the cross ILWC $140 \times$ Jimbour) were also included. Based on our earlier research (Thompson et al. 2011), four other reference wild Cicer accessions were included which consisted of one resistant and one susceptible $C$. reticulatum (ILWC 123 and ILWC 184 , respectively) and one resistant and one moderately susceptible C. echinospermum (ILWC 246 and ILWC 39, respectively). Hexaploid wheats were also included as references for a range of resistance or susceptibility to $P$. thornei; namely, susceptible (Petrie and Batavia), moderately susceptible (Sunzell), moderately resistant (QT8343) (Sheedy and Thompson 2009), and resistant (CPI133872) (Zwart et al. 2005).

Assessing accessions for resistance to $P$. thornei. All accessions were tested twice, with the exception of 23 accessions comprising 14 C. reticulatum and 9 C. echinospermum, which were not available in time for experiment 1 and were tested once in experiment 2. Resistance levels for each accession were determined by final nematode populations (Pf) in the soil and roots after 18 weeks of growth. Accessions with higher Pf values were considered more susceptible than those with lower Pf values.

Both experiments were conducted in controlled-environment glasshouses with air temperatures maintained at approximately 20 to $25^{\circ} \mathrm{C}$. Under-bench heating maintained the soil temperature in pots at approximately $22^{\circ} \mathrm{C}$, the optimum temperature for $P$. thornei reproduction (Thompson et al. 2015b). Benches were fitted with a bottom-watering system set at $2 \mathrm{~cm}$ of water tension regulated by a float valve. Accessions were replicated three times in a row-column randomized block design. Single plants were grown in $70-\mathrm{mm}$ square pots (150 mm high) containing $330 \mathrm{~g}$ (oven-dry equivalent) of black Vertosol (Isbell 1996) of the Waco series (Beckmann and Thompson 1960), representative of soils in which chickpea is grown in the region. Soil was pasteurized with aerated steam at $85^{\circ} \mathrm{C}$ for 45 min (modified from Thompson [1990]). A solution-based fertilizer of nitrogen, phosphorus, and potassium (NPK) supplying $\mathrm{NO}_{3}-\mathrm{N}$ at $200 \mathrm{mg} / \mathrm{kg}$ of soil, $\mathrm{P}$ at $25 \mathrm{mg} / \mathrm{kg}$ of soil, $\mathrm{K}$ at $88 \mathrm{mg} / \mathrm{kg}$ of soil, $\mathrm{S}$ at $36 \mathrm{mg} / \mathrm{kg}$ of soil, and $\mathrm{Zn}$ at $5 \mathrm{mg} / \mathrm{kg}$ of soil was mixed with $80 \%$ of the total soil volume in each pot. In both experiments, the 
seeds of wild Cicer spp. were cut at the endosperm end with a scalpel to enable imbibition for germination. Inoculum was produced by open-pot culture on susceptible wheat (O'Reilly and Thompson 1993) using a pure culture of $P$. thornei originating from 10 specimens collected from a field at Formartin $\left(27.46401^{\circ} \mathrm{S}\right.$, $151.42616^{\circ} \mathrm{E}, 364 \mathrm{~m}$ in elevation, $70 \mathrm{~km}$ west of Toowoomba, Australia) (Thompson 2008). P. thornei nematodes were extracted from soil and roots of the cultures using the Whitehead tray method (Whitehead and Hemming 1965). The suspension of nematodes for inoculum consisted of adult females and juveniles and was adjusted to deliver 3,300 P. thornei per pot, equivalent to 10,000 nematodes/ $\mathrm{kg}$ of soil (oven-dry equivalent). Final ratios of adults to juveniles for inoculum suspensions were $32 \%$ adults and $68 \%$ juveniles for experiment 1 and $35 \%$ adults and $65 \%$ juveniles for experiment 2 . At planting, the seed was placed on top of moistened soil within each pot and inoculated with a 0.5 -ml slurry of rhizobium group $\mathrm{N}$ Mesorhizobium ciceri strain CC1192 on peat carrier. This was followed by a $10-\mathrm{ml}$ nematode suspension pipetted around the seed. Following nematode inoculation, the remaining $20 \%$ soil volume was placed to cover the seed, rhizobium, and nematode inoculum.

Plant harvest, nematode extraction, and enumeration. Plants were harvested at 18 weeks with the water supply to benches turned off approximately 2 to 3 days prior to harvest date to allow the soil to dry to approximately $45 \%$ moisture content. At harvest, the plant height and plant growth stage of chickpea (Lancashire et al. 1991) and of wheat (Zadoks et al. 1974) were recorded. Plant biomass was measured by collecting plant tops cut at soil level and dried in a forced-draft oven at $80^{\circ} \mathrm{C}$ for $48 \mathrm{~h}$. The soil from each pot was teased apart, roots were cut into approximately $10-\mathrm{mm}$ lengths, and soil and roots mixed together manually. Nematodes were extracted by the Whitehead tray method (Whitehead and Hemming 1965) by placing a $150 \mathrm{~g}$ of moist subsample of soil and roots from each pot on a single Kimwipe tissue (KIMTECH; Kimberly-Clark Worldwide, Inc.) for $48 \mathrm{~h}$ at $22^{\circ} \mathrm{C}$. Soil gravimetric moisture content was determined on a 100 -g subsample dried in a forced-draft oven at $105^{\circ} \mathrm{C}$ for $48 \mathrm{~h}$. Nematodes were collected on a $20-\mu \mathrm{m}$ aperture sieve in approximately $15 \mathrm{ml}$ of tap water, transferred into $30-\mathrm{ml}$ vials, and stored at $4^{\circ} \mathrm{C}$ until enumeration. P. thornei were counted in a 1-ml Peters slide (Peters 1952) (purchased from Chalex Corporation) under a compound microscope $(\times 40)$. Pf densities were expressed as number of nematodes per kilogram of soil and roots (oven-dried equivalent) or nematodes per gram of dry weight root, after determination of root biomass as described below.

Root biomass and $P$. thornei per gram of root. To determine whether there was any relationship between root biomass and final $P$. thornei densities, 167 chickpea and wild Cicer accessions from experiment 1 were assessed for root biomass. To assess root biomass, the $150 \mathrm{~g}$ subsample of soil and roots was retained immediately following nematode extractions and stored at $4^{\circ} \mathrm{C}$ in polypropylene plastic food containers $(90 \mathrm{~mm}$ in diameter by $83 \mathrm{~mm}$ in height) until extraction of roots within the following 1 to 4 days. The roots were recovered by transferring each soil sample to a 10-liter bucket of tap water. Roots and soil were then manually agitated and decanted onto a sieve (250- $\mu \mathrm{m}$ aperture) to collect roots, which were washed under running tap water for further cleaning. This process was repeated several times until all roots were recovered from the sample. For final cleaning, the roots were returned to the original containers and the containers filled with water to allow further settling of any remaining sediment; floating debris was removed manually. The suspension of roots was then manually agitated and decanted onto a sieve (250- $\mu \mathrm{m}$ aperture) for final collection of roots. The roots were blotted with paper toweling, then dried in a forceddraft oven at $65^{\circ} \mathrm{C}$ for 4 days and values expressed as dry weight root per kilogram of soil. Determining root biomass enabled $P$. thornei numbers to be expressed as $P$. thornei per gram of dry weight root.

Statistical design and analyses. Linear mixed models were used to analyze $P$. thornei population densities by the residual maximum-likelihood procedure (Patterson and Thompson 1971) within the ASReml-R package (Butler et al. 2009) in the R software environment (R Core Team 2018). A logarithmic transformation $\log _{\mathrm{e}}(x)$ was required for the analysis of $P$. thornei per kilogram (soil + roots) and $P$. thornei per gram (roots) (Marks and Proctor 1974).

The primary analysis investigated genetic effects for each individual accession across the two experiments using the methods

TABLE 1. Passport information on the collection of wild chickpea accessions in terms of code number, genetic population, and species aligned with province and collection site of origin for accessions collected in 2013 from southeastern Turkey and assessed for Pratylenchus thornei resistance ${ }^{y}$

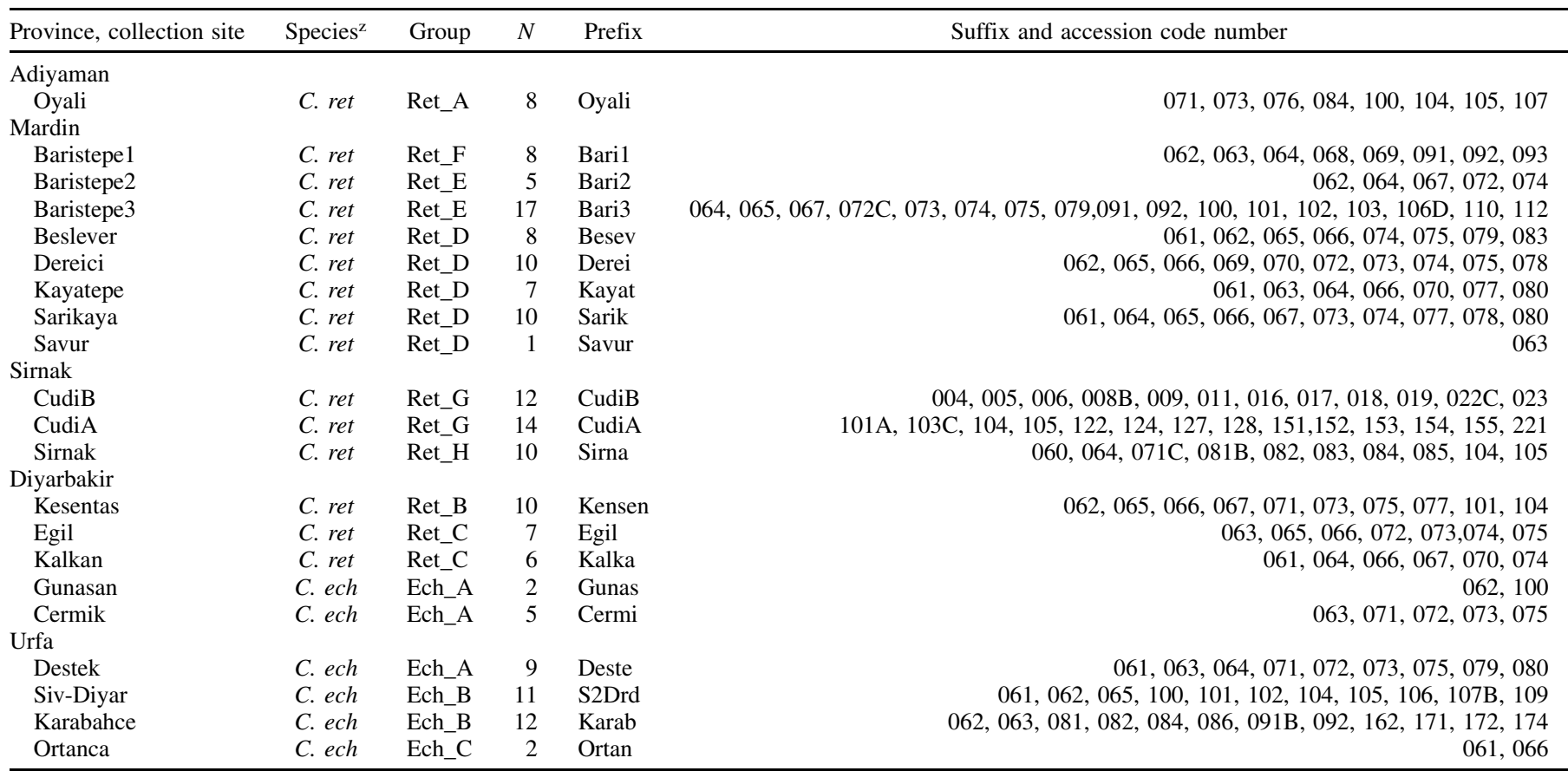

y All wild Cicer accessions are identified by an original collection code number supplied by the Australian Grains Genebank (AGG). Group = genetic population group, $N=$ number of accessions, and Prefix $=$ code name used before the suffix number.

z Abbreviations: C. ret. $=$ Cicer reticulatum (wild Cicer) and C. ech. $=$ C. echinospermum (wild Cicer). 
proposed by Smith et al. (2001). Because the main objective was genetic selection of resistance, experiment was fitted as a fixed effect while accession was considered as random. The genetic correlation between the two experiments was also estimated (Smith et al. 2001), resulting in accession predictions that were empirical best linear unbiased predictors (BLUPs). Residual variances were estimated for each experiment separately and spatial trend was accounted for using the methods of Gilmour et al. (1997).

Subsidiary analyses were performed to investigate whether significant differences existed between accessions nested within (i) Cicer spp., (ii) provinces, (iii) collection sites, and (iv) genetic population groups. Each of the subsidiary analyses was performed for each experiment separately, giving a total of eight subsidiary analyses. Contrasts were set up to test commercial cultivars and wild relatives as two separate groups for the nested variables and their interactions (Bell and Mumford 2017). In order to set up the contrasts, the corresponding nested variables were fitted as fixed effects, resulting in empirical best linear unbiased estimators (BLUEs). Comparisons of significant differences within the corresponding nested variable were completed using Fisher's protected least significant difference testing.

Reproduction factors (RF) were calculated as the ratio of the final population density of nematodes divided by the initial inoculation rate, both expressed per kilogram of soil. From the combined analysis, genotypes with final population densities significantly $(P<0.05)$ less than $C$. echinospermum ILWC 246 (RF range 0.28 to 0.40 ) were rated resistant while those significantly less than chickpea cultivar PBA Seamer (RF range 0.41 to 0.65 ) were rated moderately resistant.

\section{RESULTS}

Final $P$. thornei population densities (Pf) for accessions. In each experiment, $P$. thornei population densities were continuously distributed with significant $(P<0.001)$ differences between accessions. Population densities of $P$. thornei in experiment 1 ranged from the most resistant wild accession Oyali_071 (990 nematodes $/ \mathrm{kg}$ of soil + roots) to susceptible chickpea reference cultivar Kyabra (89,199 nematodes $/ \mathrm{kg}$ ) (data not shown). Overall, 29 (19\%) wild Cicer accessions produced fewer P. thornei than the unplanted reference treatment $(3,337$ nematodes $/ \mathrm{kg})$. For the wheat references, population densities of $P$. thornei ranged from 3,380 nematodes/kg for the resistant synthetic hexaploid wheat CPI133872 to 87,566 nematodes $/ \mathrm{kg}$ for susceptible Petrie.

In experiment 2, P. thornei population densities for wild Cicer accessions ranged from 3,041 nematodes $/ \mathrm{kg}$ for ILWC 123 to 108,012 nematodes/kg for Savur_063. Twenty (11\%) of the wild Cicer accessions had lower population densities than the unplanted reference $(4,915$ nematodes $/ \mathrm{kg})$. The reference wheat accessions ranged from 5,432 nematodes/kg for resistant synthetic wheat CPI133872 to 271,034 nematodes/kg for susceptible Petrie (data not shown).

A multienvironment trial analysis was performed on the entire data set of chickpea and wild Cicer accessions across both experiments to determine the overall ranking of accessions for resistance. In each experiment, predictions were calculated separately (Fig. 1) and with the correlation between the experiments being strong $(r=0.844)$. genetic predictions (BLUPs) for the common accessions were averaged across the two experiments. Values ranged from the most resistant C. reticulatum Bari1_091 (2,844 nematodes/ $\mathrm{kg}$ of soil, RF 0.28$)$ to the susceptible reference Kyabra $(55,167$ nematodes/kg, RF 5.52), while C. reticulatum Savur_063 (41,794 nematodes/kg, RF 4.18) was the most susceptible of the new accessions tested. The chickpea cultivar with the lowest population density was ICC11323 (10,834 nematodes/kg, RF 1.08), followed by Australian cultivars PBA Seamer (11,175 nematodes/kg, RF 1.12), PBA Pistol (11,215 nematodes/kg, RF 1.12), and PBA HatTrick (18,887 nematodes/kg, RF 1.89). In total, 53 (30\%) wild Cicer accessions were significantly $(P \leq 0.05)$ more resistant than the best Australian cultivar PBA Seamer, with $38(21 \%)$ of these more resistant than ICC11323 and 13 (8\%) more resistant than ILWC 246 (7,431 nematodes $/ \mathrm{kg}$ ). For the wild Cicer reference cultivars, ILWC $123(2,931$ nematodes $/ \mathrm{kg})$ was significantly $(P<0.05)$ more resistant than ILWC 246. The full data set is available in Supplementary Table $\mathrm{S} 1$ and the frequency distribution of the BLUPs of $\log _{\mathrm{e}}$ (P. thornei nematodes $/ \mathrm{kg}$ of soil + roots) for all accessions is given in Figure 2. A summary of final $P$. thornei population densities for chickpea cultivars and wild accessions that were significantly more resistant than ILWC 246 is given in Table 2.

$P$. thornei population densities for the 26 diverse wild accessions (20 C. reticulatum and 6 C. echinospermum) selected internationally for trait marker association studies, and in Australia crossed with PBA HatTrick, revealed that 11 of the 26 produced lower

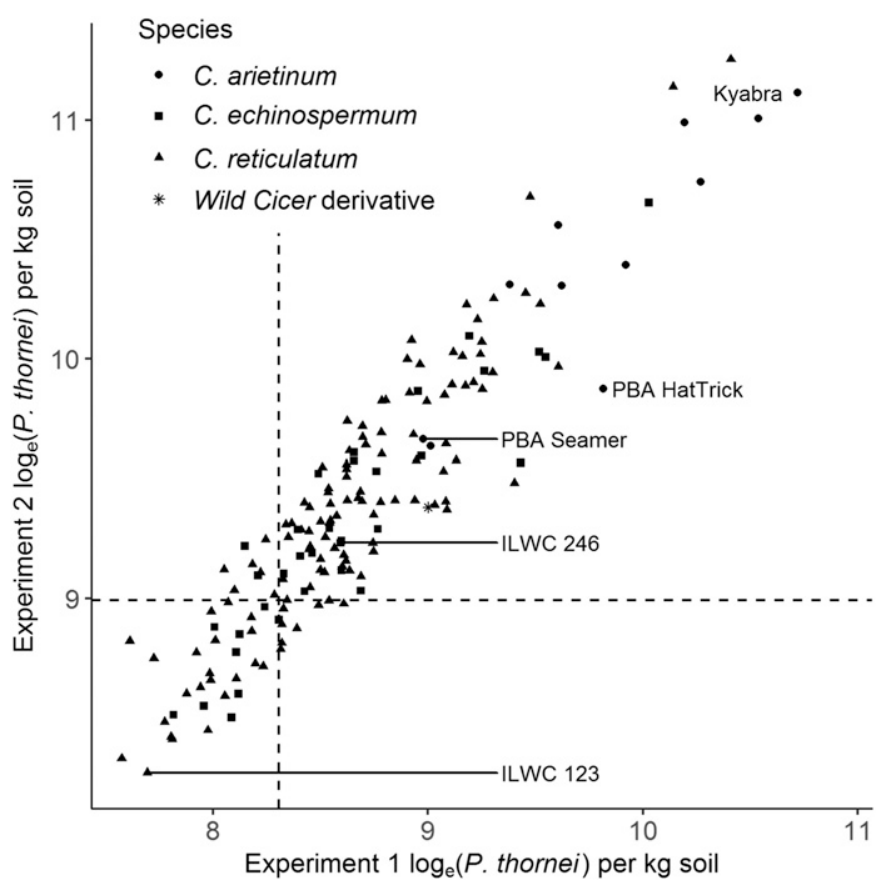

Fig. 1. Accession means (best linear unbiased predictors) of Pratylenchus thornei population densities for Cicer accessions included in both experiments showed a strong genetic correlation between experiments $(r=0.844, n=167)$. Vertical and horizontal dashed lines denote the cut-off points for the top $20 \%$ genotypes for resistance to $P$. thornei.

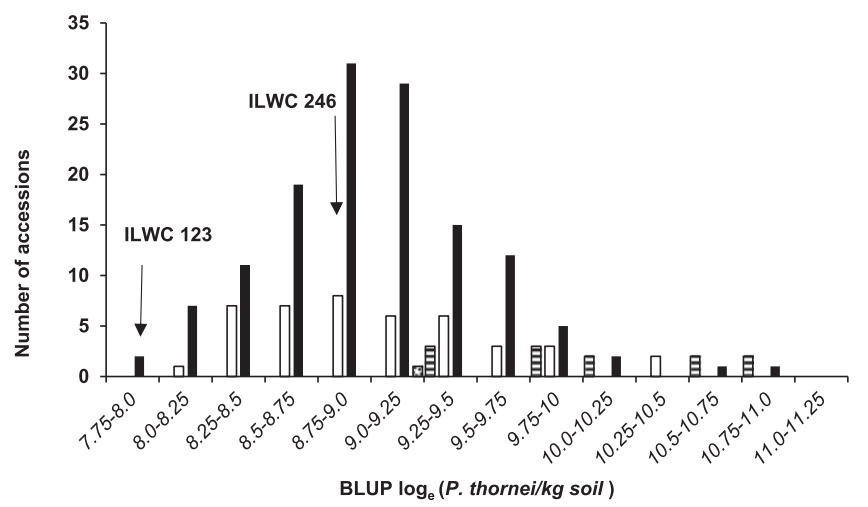

घC. arietinum $\square$ C. echinospermum $\square$ C. reticulatum Wild Cicer derivative

Fig. 2. Frequency distributions of chickpea and wild Cicer accessions from combined analysis of two experiments in classes of best linear unbiased predictions (BLUPs) of $\log _{\mathrm{e}}$ (number of Pratylenchus thornei nematodes per kilogram of soil + roots) after 18 weeks of plant growth. 
P. thornei population densities than ILWC 246. Of these 11 accessions, 2 of them-Gunas_062 (3,514 nematodes/kg, RF 0.35) and Kayat_077 (3,790 nematodes/kg, 0.38)—produced significantly $(P<0.05)$ lower population densities than ILWC 246 (Fig. 3).

$P$. thornei population densities according to species, province, collection sites, and genetic populations. The number of accessions for each collection site varied from 1 to 17 and, due to the extra 23 accessions in experiment 2, numbers varied within the provinces, sites, and genetic populations for each experiment. Seed of accessions from one site (Guvenli) were not available for testing, resulting in assessment of 11 genetic population groups out of the 12 identified for this collection by Von Wettberg et al. (2018).

The results indicated significant $(P<0.05)$ interactions between genotype and (i) species, (ii) province, (iii) collection site, and (iv) genetic population group. Based on individual analysis for species, both experiments showed that, on average, accessions of the wild species $C$. reticulatum and $C$. echinospermum were equal in terms of $P$. thornei resistance, with accessions of both species significantly $(P<0.001)$ more resistant than $C$. arietinum (Table 3$)$.

Mean population densities of $P$. thornei differed significantly $(P<0.001)$ among the five provinces in each of the experiments (Table 4). Accessions from the Adiyaman province had the lowest mean population densities for each of the two experiments, with 2,868 and 9,555 P. thornei nematodes/kg of soil, respectively, while the Sirnak province had the most susceptible accessions for both experiments, with 6,960 and 14,600 nematodes $/ \mathrm{kg}$ of soil, respectively.

For each of the 21 collection sites, mean $P$. thornei population densities differed significantly $(P<0.001)$, as did individual accessions within the sites. The Oyali site had the lowest mean
P. thornei population densities in experiment 1 (2,533 nematodes $/ \mathrm{kg})$ while Gunasan, with two accessions, had the lowest in experiment 2 (5,064 nematodes $/ \mathrm{kg}$ ). Overall mean $P$. thornei population densities were lowest for accessions from Kayatepe, with $P$. thornei population densities not exceeding 7,044 nematodes $/ \mathrm{kg}$. The Savur site, where only one accession originated, was the most susceptible in both experiments, with population densities of $P$. thornei of 22,902 and 108,102 nematodes $/ \mathrm{kg}$ of soil in experiments 1 and 2, respectively (Fig. 4). The range of $P$. thornei population densities for each

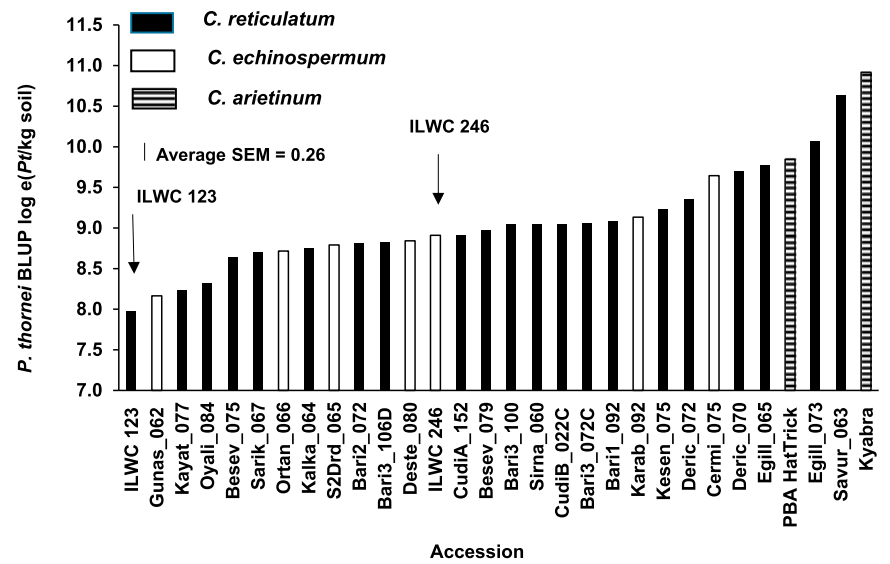

Fig. 3. Pratylenchus thornei densities as $P$. thornei best linear unbiased predictors (BLUPs; nematodes per kilogram of soil + roots) for 26 diverse wild Cicer selected internationally for nested association mapping studies compared with breeding parent PBA HatTrick, susceptible Kyabra, and resistant references Cicer reticulatum ILWC 123 and C. echinospermum ILWC 246. $\mathrm{SEM}=$ standard error of the mean.

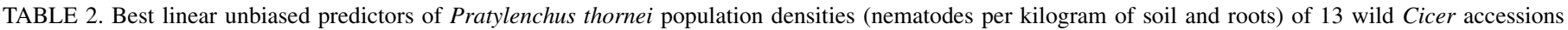

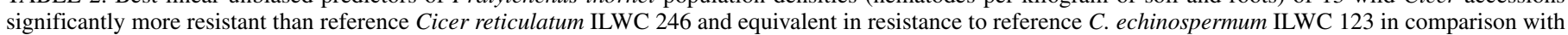
13 other chickpea reference accessions from combined analysis of two experiments

\begin{tabular}{|c|c|c|c|c|c|c|}
\hline \multirow[b]{2}{*}{ Species $^{\mathrm{v}}$} & \multirow[b]{2}{*}{ AGG accession $^{\mathrm{w}}$} & \multirow[b]{2}{*}{$\operatorname{Code}^{\mathrm{x}}$} & \multirow[b]{2}{*}{ Group $^{\mathrm{y}}$} & \multicolumn{2}{|c|}{ Nematodes $^{\mathrm{u}}$} & \multirow[b]{2}{*}{$\operatorname{Prob}^{z}$} \\
\hline & & & & $\log _{e}$ & BTM & \\
\hline C. ret & 49797 & Bari1_091 & Ret_F & 7.95 & 2,844 & 0.01 \\
\hline C. ret & ILWC 123 & & & 7.98 & 2,931 & 0.01 \\
\hline C. ret & 49967 & Kayat_063 & Ret_D & 8.11 & 3,331 & 0.02 \\
\hline C. ret & 49795 & Bari1_069 & Ret_F & 8.11 & 3,340 & 0.02 \\
\hline C. ret & 49793 & Bari1_068 & Ret_F & 8.13 & 3,392 & 0.02 \\
\hline C. ech & 50135 & Gunas_062 & Ech_A & 8.16 & 3,514 & 0.02 \\
\hline C. ret & 49931 & Deric_074 & Ret_D & 8.21 & 3,687 & 0.03 \\
\hline C. ret & 50003 & Oyali_071 & Ret_A & 8.22 & 3,705 & 0.03 \\
\hline C. ret & 50005 & Oyali_073 & Ret_A & 8.24 & 3,777 & 0.04 \\
\hline C. ret & 49975 & Kayat_077 & Ret_D & 8.24 & 3,790 & 0.04 \\
\hline C. ech & 50150 & Karab_082 & Ech_B & 8.25 & 3,845 & 0.04 \\
\hline C. ret & 49803 & Bari2_062 & Ret_E & 8.28 & 3,963 & 0.05 \\
\hline C. ech & 50101 & Cermi_072 & Ech_A & 8.29 & 4,001 & 0.05 \\
\hline C. ech & ILWC 246 & $\ldots$ & $\ldots$ & 8.91 & 7,431 & N/A \\
\hline C. ret der. & 00283-1095-1002 & $\ldots$ & $\ldots$ & 9.19 & 9,809 & 0.76 \\
\hline C. ariet & ICC 11323 & $\ldots$ & $\ldots$ & 9.29 & 10,834 & 0.81 \\
\hline C. ariet & PBA Seamer & $\ldots$ & $\ldots$ & 9.32 & 11,175 & 0.86 \\
\hline C. ariet & PBA HatTrick & $\ldots$ & $\ldots$ & 9.85 & 18,877 & 0.99 \\
\hline C. ariet & Yorker & $\ldots$ & $\ldots$ & 9.85 & 18,897 & 0.99 \\
\hline C. ariet & Flipper & $\ldots$ & $\ldots$ & 9.96 & 21,257 & 1.00 \\
\hline C. ariet & PBA Boundary & $\ldots$ & $\ldots$ & 10.08 & 23,941 & 1.00 \\
\hline C. ariet & Jimbour & $\ldots$ & $\ldots$ & 10.16 & 25,774 & 1.00 \\
\hline C. ariet & Sonali & $\ldots$ & $\ldots$ & 10.51 & 36,499 & 1.00 \\
\hline C. ariet & Howzat & $\ldots$ & $\ldots$ & 10.59 & 39,836 & 1.00 \\
\hline C. ariet & Sona & $\ldots$ & $\ldots$ & 10.77 & 47,670 & 1.00 \\
\hline C. ret & ILWC 184 & $\ldots$ & $\ldots$ & 10.83 & 50,654 & 1.00 \\
\hline C. ariet & Kyabra & $\ldots$ & $\ldots$ & 10.92 & 55,167 & 1.00 \\
\hline
\end{tabular}

u $P$. thornei nematodes per kilogram of soil + roots. BTM = back-transformed mean.

v Abbreviations: $C$. ret $=C$. reticulatum, $C$. ech $=C$. echinospermum, $C$. ret der $=C$. reticulatum derivative, and $C$. ariet $=C$. arietinum.

${ }^{\mathrm{w}} \mathrm{AGG}=$ Australian Grains Genebank.

$\mathrm{x}$ Accession code.

y Genetic population group.

z Probability of accession having higher P. thornei density than ILWC 246. 
collection site for the two experiments is available in Supplementary Table S2.

Analysis of the 11 genetic population groups revealed significant $(P<0.001)$ differences for mean $P$. thornei population densities (Fig. 5). Accessions in genetic population group Ret_A produced the lowest mean $(2,533$ nematodes $/ \mathrm{kg})$ for experiment 1 and Ret_F produced the lowest mean $(6,843$ nematodes $/ \mathrm{kg})$ for experiment 2 . Both of these groups were aligned with the sites Oyali and Baristepe1. Across both experiments, accessions grouped in Ret_F, aligned with the site Baristepe1, produced the lowest mean $P$. thornei population densities. The most susceptible genetic population groups were Ret_H and Ret_C in experiments 1 and 2, respectively, with accessions in both of these genetic population groups aligned with collection sites Sirnak, Egil, and Kalkan.

Correlation of root biomass with $P$. thornei population densities. To investigate the effect of root biomass on final $P$. thornei population densities, the dry root biomass was determined for 167 chickpea and wild Cicer accessions in experiment 1. C. echinospermum accessions had significantly $(P<0.001)$ greater mean root biomass $(4.94 \mathrm{~g} / \mathrm{kg}$ of soil) than $C$. reticulatum $(3.87 \mathrm{~g} / \mathrm{kg}$ of soil). However, neither wild species differed significantly in root biomass from C. arietinum $(4.16 \mathrm{~g} / \mathrm{kg}$ of soil). Individual accessions differed significantly $(P<0.001)$ in root biomass and ranged from Karab_082 $(1.02 \mathrm{~g} / \mathrm{kg}$ of soil $)$ to Deste_064 (11.63 g/kg of soil). Root biomass was greatest for C. echinospermum accessions Deste_064 (11.63 g/kg of soil) and S2Drd_065 (11.59 g/kg of soil) and C. reticulatum accessions Kalka_064 (9.01 g/kg of soil) and Kalka_074 (8.98 g/kg of soil).

TABLE 3. Population densities of Pratylenchus thornei in relation to species of Cicer best linear unbiased estimators ( $P$. thornei nematodes per kilogram of soil + roots) after 18 weeks of plant growth in experiment 1 and experiment 2

\begin{tabular}{lrrr}
\hline & & \multicolumn{2}{c}{$\begin{array}{c}\text { Nematodes } / \mathrm{kg} \text { of } \\
\text { soil + roots }\end{array}$} \\
\cline { 3 - 4 } Experiment, species & $N^{\mathrm{z}}$ & \multicolumn{1}{c}{$\log _{e}$} & BTM \\
\hline 1 Cicer arietinum & & $10.13 \mathrm{a}$ & 25,804 \\
C. echinospermum & 11 & $8.61 \mathrm{~b}$ & 5,503 \\
C. reticulatum & 34 & $8.59 \mathrm{~b}$ & 5,359 \\
2 & 121 & $10.42 \mathrm{a}$ & 33,390 \\
C. arietinum & & $9.38 \mathrm{~b}$ & 11,897 \\
C. reticulatum & 12 & $9.35 \mathrm{~b}$ & 11,487 \\
C. echinospermum & 135 & 43 &
\end{tabular}

y Values followed by the same letter within each experiment are not significantly different $(P<0.05)$. BTM $=$ back-transformed mean.

z Number of accessions.

TABLE 4. Population densities of Pratylenchus thornei (number of nematodes per kilogram of soil + roots) after 18 weeks growth of wild Cicer accessions in relation to provinces of origin in Turkey

\begin{tabular}{|c|c|c|c|c|}
\hline \multirow{2}{*}{$\begin{array}{l}\text { Experiment, } \\
\text { province }\end{array}$} & \multicolumn{2}{|c|}{ Number of accessions } & \multicolumn{2}{|c|}{$\begin{array}{c}\text { Nematodes } / \mathrm{kg} \text { of } \\
\text { soil }+ \text { roots }^{\mathrm{z}}\end{array}$} \\
\hline & C. reticulatum & C. echinospermum & $\log _{e}$ & BTM \\
\hline \multicolumn{5}{|l|}{1} \\
\hline Sirnak & 27 & $\ldots$ & $8.85 \mathrm{a}$ & 6,960 \\
\hline Urfa & $\ldots$ & 25 & $8.68 \mathrm{ab}$ & 5,888 \\
\hline Diyarbakir & 22 & 5 & $8.59 \mathrm{~b}$ & 5,395 \\
\hline Mardin & 64 & $\ldots$ & $8.52 \mathrm{~b}$ & 5,000 \\
\hline Adiyaman & 8 & $\ldots$ & $7.96 \mathrm{c}$ & 2,868 \\
\hline \multicolumn{5}{|l|}{2} \\
\hline Sirnak & 36 & $\ldots$ & $9.59 \mathrm{a}$ & 14,600 \\
\hline Diyarbakir & 23 & 7 & $9.48 \mathrm{ab}$ & 13,144 \\
\hline Urfa & $\ldots$ & 34 & $9.37 \mathrm{bc}$ & 11,759 \\
\hline Mardin & 66 & $\ldots$ & $9.23 \mathrm{~d}$ & 10,162 \\
\hline Adiyaman & 8 & $\ldots$ & $9.16 \mathrm{~cd}$ & 9,555 \\
\hline
\end{tabular}

z Values followed by the same letter are not significantly different $(P<0.05)$. $\mathrm{BTM}=$ back-transformed mean.
Correlation analysis for the accessions showed no significant relationship ( $r=0.11)$ between final $P$. thornei population densities and root biomass. In contrast, there was a highly significant genetic correlation $(r=0.88, P<0.001)$ between the population density of $P$. thornei expressed on a root weight basis or on a soil and root weight basis (Fig. 6). This indicated that differences among accessions in amount of root produced were not a major influence on nematode population densities and on interpretation of the levels of resistance or susceptibility of the accessions.

Plant maturity. Plant maturity of chickpea accessions at 18 weeks ranged from preflowering to full pod ripening (data not shown). For C. echinospermum accessions, $28 \%$ were at preflowering stage, $60 \%$ at flowering, and $12 \%$ at podding. Similarly, $22 \%$ of C. reticulatum accessions were at preflowering stage, $51 \%$ flowering, $26 \%$ podding, and $1 \%$ at pod ripening stage. C. arietinum accessions ranged from pod ripening stage to full maturity. Overall, C. reticulatum had a larger percentage of accessions at the podding stage compared with $C$. echinospermum. Although there were significant differences among accessions in numeric scores for plant maturity $(P<0.001)$, there was no significant correlation between $P$. thornei population density and the numeric score for plant growth stage, with $P=0.31$ for experiment 1 and $P=0.27$ for experiment 2 .

\section{DISCUSSION}

This is the first study characterizing a new, more expansive collection of $C$. reticulatum and $C$. echinospermum accessions for resistance to a plant-parasitic nematode species; namely, $P$. thornei.
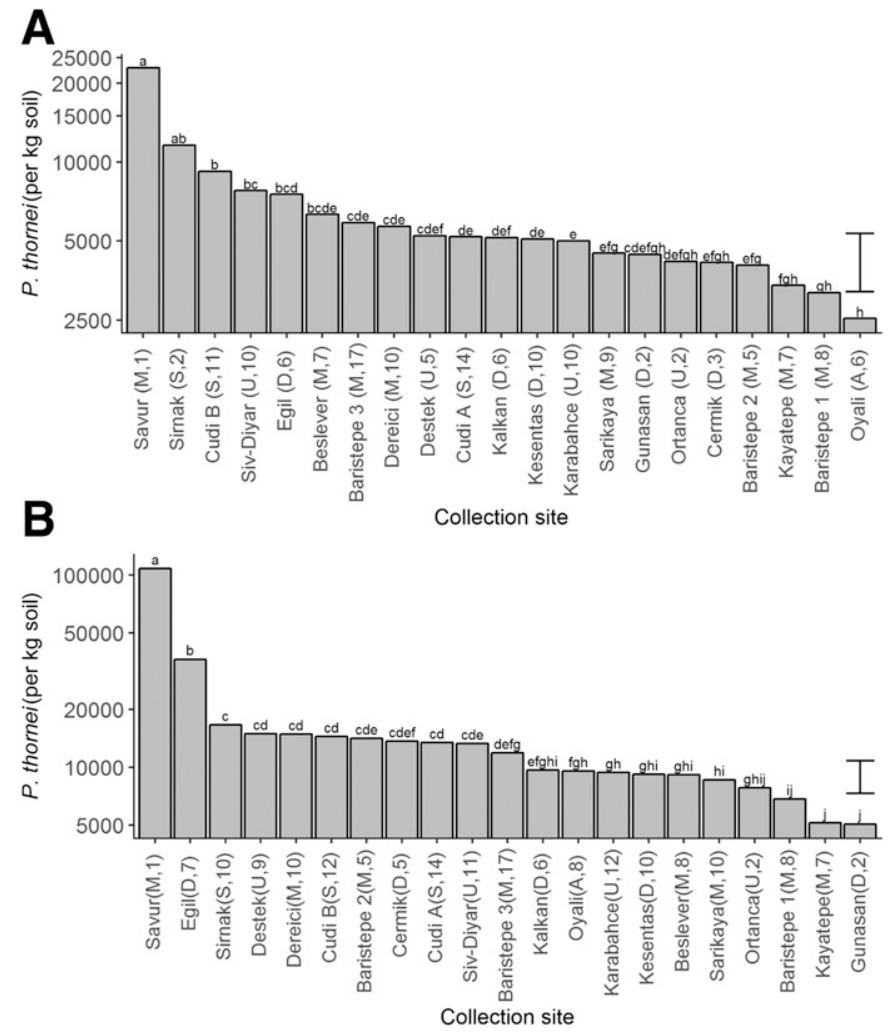

Fig. 4. Back-transformed means (best linear unbiased estimators) for population densities of Pratylenchus thornei nematodes per kilogram of soil for wild Cicer accessions from the 21 collection sites in southeast Turkey in $\mathbf{A}$, experiment 1 and $\mathbf{B}$, experiment 2 . The letter in parenthesis after the site name indicates the Turkish province from east to west, where $\mathrm{S}=\mathrm{Sirnak}, \mathrm{M}=$ Mardin, $\mathrm{D}=$ Diyarbakir, $\mathrm{U}=\mathrm{Urfa}$, and $\mathrm{A}=$ Adiyaman. The number in parentheses indicates the number of accessions from the collection site in each experiment. Collection sites without a common letter are significantly different $(P \leq 0.05)$. The vertical bar represents the average least significant difference value across the 21 collection sites. 
On average, the wild Cicer spp. or accessions exhibited higher levels of resistance to $P$. thornei than the cultivated varieties (C. arietinum) assessed in this study. This agrees with earlier studies (Thompson et al. 2011), where improved levels of resistance were identified in a much smaller collection of accessions of 18 original C. reticulatum and 10 original C. echinospermum. The current study revealed a range of resistance within accessions for both wild species, with neither species appearing the more resistant. In contrast, in an earlier study with a limited number of accessions, C. echinospermum tended to have a distribution toward greater resistance than $C$. reticulatum (Thompson et al. 2011). A larger number of C. echinospermum and C. reticulatum accessions (41 and 133 , respectively) from new collection sites were assessed in this current study compared with the earlier study and evaluation of a larger sample size has better characterized the resistance status of the two wild species.

Accessions in the new collection originated from a narrow geographical area that nonetheless spanned a range of physical and environmental scales based on climate and soil type, including a large elevational gradient ( 740 to $1,695 \mathrm{~m}$ ) that was shown to affect genetic differentiation more than geographic distance (Von Wettberg et al. 2018). Furthermore, that study found that $C$. reticulatum specimens tended to occur at higher elevation than $C$. echinospermum. Also, C. reticulatum was found on soils developed from limestone and sandstone and $C$. echinospermum on soils developed from basalt, suggesting different edaphic requirements for the two species. In our study, there appeared to be no obvious trends for association of

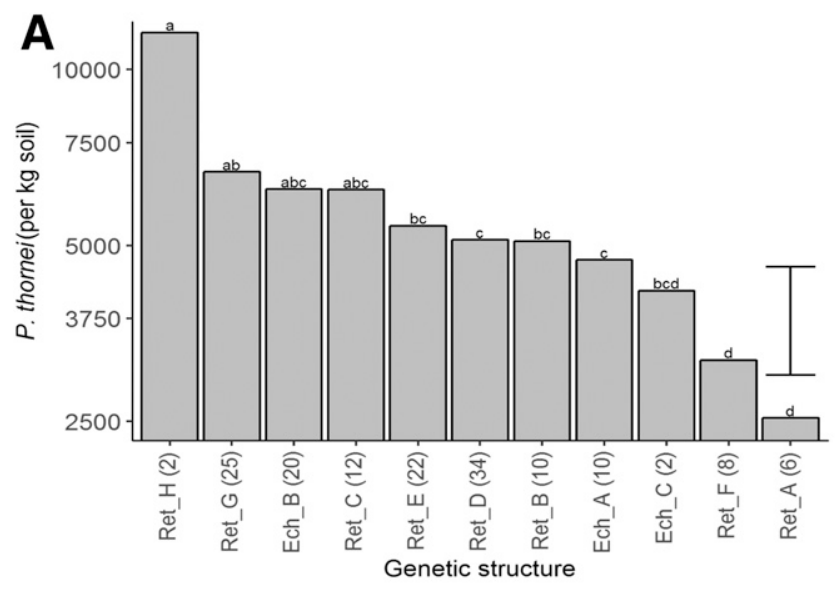

B

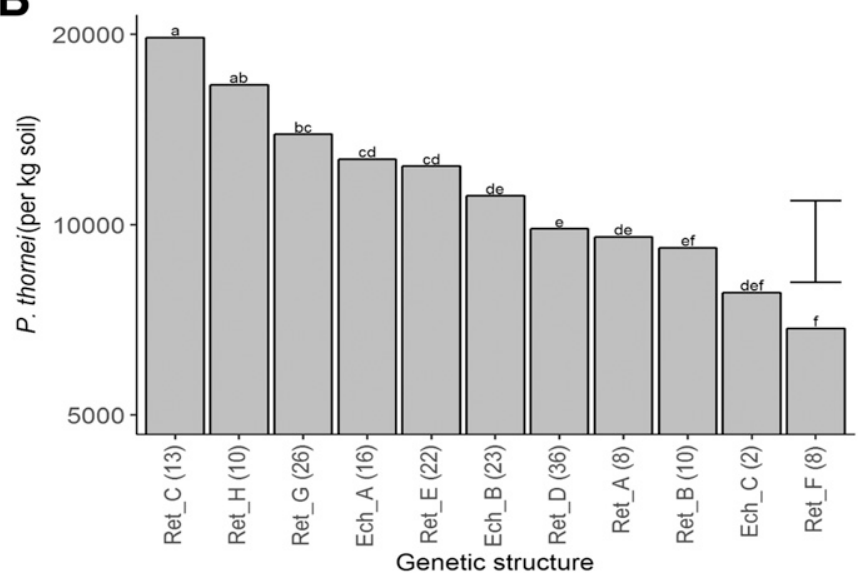

Fig. 5. Back-transformed means (best linear unbiased estimators) for population densities of wild Cicer accessions based on the 11 genetic population groups in $\mathbf{A}$, experiment 1 and $\mathbf{B}$, experiment 2 . Numbers in parenthesis indicate the number of accessions in a genetic population group in each experiment. Genetic population groups without a common letter are significantly different $(P \leq 0.05)$. The vertical bar represents the average least significant difference value across the 11 genetic population groups.
P. thornei resistance in terms of elevation and geographic distance because resistant accessions occurred at all elevations and at all sites, with the exception of the one and only accession from Savur. For example, this accession from Savur was the most susceptible and neighbored Kayatepe, where some of the most resistant accessions originated.

Von Wettberg et al. (2018) found evidence of ancestral gene flow from the wild relative $C$. bijugum into $C$. reticulatum at sites Oyali (17.1\% C. bijugum DNA) and Kesentas (11.9\% C. bijugum DNA). Interestingly, Thompson et al. (2011) found that a higher proportion of $C$. bijugum accessions had partial resistance to $P$. thornei than the C. reticulatum accessions tested. In the present study, these sites (Oyali and Kesantas) provided $C$. reticulatum accessions that tended to be more resistant to $P$. thornei than many of the other collection sites. Currently, C. bijugum cannot be successfully crossed with $C$. arietinum (Li et al. 2015) and these accessions of C. reticulatum from Oyali and Kesentas might provide a natural bridge to introgress novel resistance genes from $C$. bijugum into C. arietinum.

Our current study identified significant differences among the genetic population groups of wild Cicer spp. for mean $P$. thornei population densities. Predominantly, the genetic population groups identified by Von Wettberg et al. (2018) were linked to the site of origin for each accession and our analysis identified lower mean P. thornei population densities for accessions grouped under Ret_A and Ret_F. Interestingly, these two genetic groups aligned with the sites Oyali and Baristepe1, located at elevations below 1,000 m, while the most susceptible genetic population groups Ret_H and Ret_C aligned with the sites Sirnak, Egil, and Kalkhan, which were situated at elevations of 1,659, 986, and $840 \mathrm{~m}$, respectively. However, similar to our findings, for accessions within the collection sites, there appeared to be no distinct trend for association of resistance with elevation or geographic distance.

The foremost trait to reduce soil populations of $P$. thornei is resistance, and our current study highlights a diverse, abundant, and stronger source of resistance, with $53(30 \%)$ of wild accessions identified as more resistant than PBA Seamer, the most resistant Australian cultivar in this study. A recent study based on a single glasshouse experiment by Rodda et al. (2016) noted the recently developed commercial cultivar PBA Seamer (formerly CICA 0912) to be equal in resistance to ILWC 246, PBA HatTrick, and the specifically bred lines for $P$. thornei resistance CICA1432 and CICA1433, both derived from ILWC 246. Currently, PBA HatTrick is cited as offering the best level of resistance; however, to incorporate $P$. thornei resistance, past breeding efforts targeted disease resistance to Ascochyta rabei (Ascochyta blight) and Phytophthora medicaginis from wild Cicer spp. rather than Pratylenchus thornei, and this has

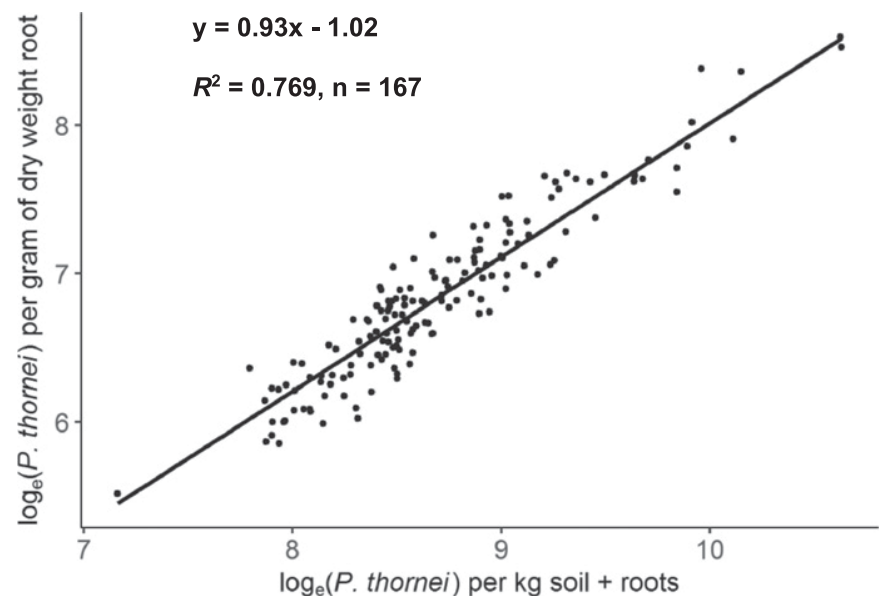

Fig. 6. Relationship between the predictions (best linear unbiased predictors) $\log _{\mathrm{e}}$ (Pratylenchus thornei) expressed per gram of dry weight root or per kilogram of soil + roots in experiment 1 . 
hindered selection for $P$. thornei (Knights et al. 2008; Rodda et al. 2016). Our present results identified 13 wild accessions more resistant than ILWC 246, which offer the opportunity to exploit this resistance and broaden the base of current $P$. thornei resistance in chickpea cultivars.

Root biomass correlations with $P$. thornei population densities. In defining plant genotype resistance, nematode population densities can be assessed in terms of nematodes per unit mass of root, or on a whole-plant or pot basis as nematodes per unit mass of soil plus roots. Some wild Cicer spp. have been observed as having less root mass than cultivated chickpea (Kashiwagi et al. 2005). There have been concerns that genotypes that produce smaller root mass may result in lower Pf densities per plant or per unit weight of soil and roots and, therefore, accessions appear resistant. Limited research has been conducted in this area (Starr et al. 2002); therefore, in this study, we determined whether there were any correlations between root biomass and final $P$. thornei population densities.

Root biomass for both $C$. reticulatum and $C$. echinospermum accessions was similar to cultivated chickpea $C$. arietinum. This agrees with the study by Kashiwagi et al. (2005), who assessed roots after 35 days (earlier than in our study) and found that $C$. reticulatum and cultivated chickpea produced similar root biomass. They found that other wild species produced less root biomass but $C$. echinospermum was not part of their study. Although our study found that root biomass differed significantly among accessions, we found it had no significant influence on the characterization of Cicer genotypes for resistance or susceptibility to $P$. thornei, with there being no significant correlation between root biomass and final $P$. thornei population densities. Nonetheless, this is not to be confused with plants that grow poorly and have very weak root systems that will not support nematode reproduction. Root biomass and root architecture are important traits for drought tolerance and grain yield in crops (Kashiwagi et al. 2005, 2006; Robinson et al. 2018). Notably, the two accessions with maximum root biomass-C. echinospermum Deste_064 (11.63 g/kg of soil) and S2Drd_065 (11.59 g/kg of soil)—also produced low population densities of $P$. thornei across the two experiments, with means of 5,448 and 6,576 nematodes/kg of soil, respectively. Similarly, accessions of C.reticulatum Kayat_063 (7.37 g/kg of soil), Kayat_077 (7.96 g/kg of soil), and C. echinospermum S2Drd_107B (8.09 g/kg of soil) had final $P$. thornei mean populations below 5,000 nematodes $/ \mathrm{kg}$, with Kayat_063 being the third most resistant accession in this study. These accessions could be valuable for simultaneously introgressing desirable root production traits and $P$. thornei resistance into elite chickpea cultivars.

Designation of resistance. Resistance to $P$. thornei in chickpea appears to be a quantitative trait (Thompson et al. 2011), which was reinforced by the results of this study, where the range of Pf densities after growth of the accessions showed continuous variation. Thus, for comparison of genotypes, the quantitative values $P$. thornei nematodes per kilogram of soil as BLUPs provide accurate genetic rankings of the accessions. Another approach to assessing resistance of genotypes is to compare RF values and we have indicated these for some individual accessions, where appropriate, in the Results section. These RF values based on BLUPs are statistically conservative estimates. They are also conservative in that they have not been adjusted for the extraction factor which, for the Whitehead method used here, is $70 \%$ (Thompson et al. 2010). Furthermore, the inoculum density used in the denominator of RF is an overestimate because not all inoculated nematodes of $P$. thornei initiate reproduction, resulting in an underestimated RF value (O'Brien 1982; Thompson et al. 2015a). To categorize the best accessions as resistant or moderately resistant, we have preferred to compare them to reference genotypes included in both experiments where those called resistant had $P$. thornei population densities significantly less than C. echinosperimum ILWC 246 and moderately resistant had significantly less than the Australian chickpea cultivar PBA Seamer.
Multiple resistance. Cultivars with multiple disease resistance are desirable in most breeding programs, with wild Cicer spp. being a valuable source of multiple resistances compared with C. arietinum (Croser et al. 2003). Moreover, the value of wild chickpea species in resistance breeding is crucial to maintain crop productivity, particularly in crops where genetic diversity is low and disease pressure results in virulent biotypes (Kameswara Rao et al. 2003), such as in the fungal diseases Ascochyta bight (A. rabei) and Fusarium wilt (Fusarium oxysporum f. sp. ciceris), both major constraints in global chickpea production (Croser et al. 2003; Li et al. 2015). Little Ascochyta resistance has been recovered from world germplasm collections but improved resistance was identified in two $C$. echinospermum accessions (Collard et al. 2003; Reddy and Singh 1984, 1992). Furthermore, Fusarium wilt, while not a major disease in Australia, is devastating to chickpea in countries such as India and may be exacerbated by root-lesion nematode attack (Castillo et al. 1998b, 2008). Interestingly, among the 26 diverse wild chickpea accessions that are of international interest, we identified 12 with lower final population densities of $P$. thornei than ILWC 246. Two of these $P$. thornei-resistant accessions, Gunas_062 and Ortan_066, have recently been identified with excellent resistance to pod borer (Helicoverpa armigera), a major insect pest in chickpea production areas in Australia and other countries (Von Wettberg et al. 2018). Characterizing the wild Cicer accessions in this study provides an informative profile for $P$. thornei resistance status. Our data offers plant breeders the opportunity to select from the most resistant accessions and deploy germplasm that possibly includes combined disease resistance that will be more sustainable in the development of future disease-resistant cultivars.

Crop improvement is dependent on a rich and diverse germplasm collection (Saeed et al. 2011) and current chickpea germplasm has limited diversity. Von Wettberg et al. (2018) showed that this new collection of $C$. reticulatum and $C$. echinospermum is 100 times more genetically diverse than $C$. arietinum, offering promise for a range of useful traits. Already, studies of this new wild Cicer collection have identified accessions possessing desirable agronomic traits (Talip et al. 2018). It is this genetic diversity and the unparalleled opportunities to incorporate novel genes controlling important traits such as $P$. thornei resistance that is encouraging plant breeders to utilize wild species despite potential linkage drag caused by undesirable agronomic traits (Muñoz et al. 2017). Utilizing the resistant accessions identified in this study while broadening the base of $P$. thornei resistance will also harness the new genetic variability within the collection.

In conclusion, our study provides the first evaluation of $P$. thorne $i$ resistance for wild chickpea in this new collection of accessions. Our results showed that $30 \%$ of the wild accessions were more resistant than current Australian chickpea cultivars. Furthermore, our data provides an informative repository that will allow linkages with genetic diversity studies and provide novel insights into nematode resistance. Finally, the introgression of resistant wild Cicer spp. into cultivated chickpea will reduce $P$. thorne $i$ populations in soils and allow more flexible crop rotations and increased yields. The outcome will be the availability of more effective and durable genes for resistance to $P$. thornei that can be used in chickpea breeding programs worldwide.

\section{ACKNOWLEDGMENTS}

We thank K. Owen and R. Zwart (University of Southern Queensland [USQ]) for scientific support; K. Bell (Queensland Department of Agriculture and Fisheries) for statistical guidance; H. Rostad (USQ) for technical assistance; Australian Grains Genebank for supplying the wild Cicer collection; and D. Cook, University of California Davis, CA, U.S.A. and J. Berger, Commonwealth Scientific and Industrial Research Organisation, Australia for collection and importation of the wild Cicer accessions into Australia. 


\section{LITERATURE CITED}

ABARES. 2017. Australian Crop Production, Table 17. In: ABARE Australian Crop Report, June 2017. Australian Bureau of Agricultural and Resource Economics and Sciences. http://www.agriculture.gov.au/abares/research-topics/agricultural-commodities/agricultural-commodities-trade-data\%232017

Abbo, S., Berger, J., and Turner, N. C. 2003. Viewpoint: Evolution of cultivated chickpea: Four bottlenecks limit diversity and constrain adaptation. Funct. Plant Biol. 30:1081-1087.

Andeden, E. E., Baloch, F. S., Derya, M., Kilian, B., and Özkan, H. 2013. iPBS-Retrotransposons-based genetic diversity and relationship among wild annual Cicer species. J. Plant Biochem. Biotechnol. 22:453-466.

Ballard, R. A., Hutton, R. E., Taylor, S. P., McKay, A. C., and Howie, J. H. 2006. Field resistance of annual pasture legumes to the root-lesion nematode, Pratylenchus neglectus. Australas. Plant Pathol. 35:303-308.

Beckmann, G., and Thompson, C. 1960. Soils and Land Use in the Kurrawa Area, Darling Downs, Queensland. CSIRO, Melbourne, Victoria, Australia.

Bell, K. L., and Mumford, M. H. 2017. Challenges analysing combined agricultural field trials with partially overlapping treatments. Page 36 in: Proc. Int. Biometrics Soc. Australas. Region Conf. http://www.biometrics.org.au/ conferences/Kingscliff2017website/biometric2017.org/wp-content/uploads/ 2017/11/Biometrics-By-The-Border-International-Biometrics-SocietyAustralas.pdf

Butler, D. G., Cullis, B. R., Gilmour, A. R., and Gogel, B. J. 2009. ASReml-R Reference Manual. The State of Queensland Department of Primary Industries and Fisheries, Brisbane, QLD Australia.

Carrasco-Ballesteros, S., Castillo, P., Adams, B. J., and Pérez-Artés, E. 2007. Identification of Pratylenchus thornei, the cereal and legume root-lesion nematode, based on SCAR-PCR and satellite DNA. Eur. J. Plant Pathol. 118:115-125.

Castillo, P., Mora-Rodríguez, M. P., Navas-Cortés, J. A., and Jiménez-Díaz, R. M. 1998b. Interactions of Pratylenchus thornei and Fusarium oxysporum f. sp. ciceris on chickpea. Phytopathology 88:828-836.

Castillo, P., Navas-Cortés, J. A., Landa, B. B., Jiménez-Díaz, R. M., and Vovlas, N. 2008. Plant-parasitic nematodes attacking chickpea and their in planta interactions with rhizobia and phytopathogenic fungi. Plant Dis. 92: 840-853.

Castillo, P., Vovlas, N., and Jiménez, D. 1998a. Pathogenicity and histopathology of Pratylenchus thornei populations on selected chickpea genotypes. J. Plant Pathol. 47:370-376.

Chauhan, Y., Allard, S., Williams, R., Williams, B., Mundree, S., Chenu, K., and Rachaputi, N. C. 2017. Characterisation of chickpea cropping systems in Australia for major abiotic production constraints. Field Crops Res. 204: 120-134.

Collard, B. C. Y., Pang, E. C. K., and Taylor, P. W. J. 2003. Selection of wild Cicer accessions for the generation of mapping populations segregating for resistance to Ascochyta blight. Euphytica 130:1-9.

Cook, R., and Evans, K. 1987. Resistance and tolerance. Pages 179-231 in: Principles and Practice of Nematode Control in Crops. R. H. Brown and B. R. Kerry, eds. Academic Press, Sydney, NSW Australia.

Croser, J. S., Ahmad, F., Clarke, H. J., and Siddique, K. H. M. 2003. Utilisation of wild Cicer in chickpea improvement-Progress, constraints, and prospects. Aust. J. Agric. Res. 54:429-444.

Dalal, R. C., Strong, W. M., Weston, E. J., Cooper, J. E., Wildermuth, G. B., Lehane, K. J., King, A. J., and Holmes, C. J. 1998. Sustaining productivity of a Vertisol at Warra, Queensland, with fertilisers, no-tillage, or legumes. 5. Wheat yields, nitrogen benefits and water-use efficiency of chickpeawheat rotation. Aust. J. Exp. Agric. 38:489-501.

Di Vito M., Zaccheo G. and Catalano F. 1995. Response of chickpea lines to Meloidogyne artiella and Pratylenchus thornei. Suppl. Nematol. Medit. 23:81-83.

FAOSTAT. 2017. Crops. Food and Agriculture Organisation of the United Nations. http://www.fao.org/faostat/en/\#data/QC

Felton, W. L., Marcellos, H., Alston, C., Martin, R. J., Backhouse, D., Burgess, L. W., and Herridge, D. F. 1998. Chickpea in wheat-based cropping systems of northern New South Wales. II. Influence on biomass, grain yield, and crown rot in the following wheat crop. Aust. J. Agric. Res. 49:401-408.

Fortuner, R. 1977. Pratylenchus thornei. In: C.I.H. Description of PlantParasitic Nematodes, Set 7, No. 93. Commonwealth Institute of Helminthology, St. Albans, U.K.

France, R. A., and Brodie, B. B. 1996. Characterisation of Pratylenchus penetrans from ten geographically isolated populations based on their reaction on potato. J. Nematol. 28:520-526.

Gilmour, A. R., Cullis, B. R., and Verbyla, A. P. 1997. Accounting for natural and extraneous variation in the analysis of field experiments. J. Agric. Biol. Environ. Stat. 2:269-293.

GRDC. 2019. 2019 Queensland Winter Crop Variety Sowing Guide. Australian Government Grains Research and Development Corporation. https:// grdc.com.au/resources-and-publications/all-publications/publications/2019/ queensland-winter-crop-variety-sowing-guide

Isbell, R. F. 1996. The Australian Soil Classification, rev. ed. CSIRO Publishing, Melbourne, VIC Australia.

Kameswara Rao, N., Reddy, L. J., and Bramel, P. J. 2003. Potential of wild species for genetic enhancement of some semi-arid food crops. Genet. Resour. Crop Evol. 50:707-721.

Kashiwagi, J., Krishnamurthy, L., Crouch, J. H., and Serraj, R. 2006. Variability of root length density and its contributions to seed yield in chickpea (Cicer arietinum L.) under terminal drought stress. Field Crops Res. 95: 171-181.

Kashiwagi, J., Krishnamurthy, L., Upadhyaya, H. D., Krishna, H., Chandra, S., Vadez, V., and Serraj, R. 2005. Genetic variability of drought-avoidance root traits in the mini-core germplasm collection of chickpea (Cicer arietinum L.). Euphytica 146:213-222.

Knights, E. J., Southwell, R. J., Schwinghamer, M. W., and Harden, S. 2008. Resistance to Phytophthora medicaginis Hansen and Maxwell in wild Cicer species and its use in breeding root rot resistant chickpea (Cicer arietinum L.). Aust. J. Agric. Res. 59:383-387.

Koseoglu, K., Adak, A., Sari, D., Sari, H., Oncu Ceylan, F., and Toker, C. 2017. Transgressive segregations for yield criteria in reciprocal interspecific crosses between Cicer arietinum L. and C. reticulatum Ladiz. Euphytica 213:116.

Kozgar, M. I. 2014. Pages 1-6 in: Mutation Breeding in Chickpea: Perspectives and Prospects for Food Security. De Gruyter Open, Warsaw, Poland.

Ladizinsky, G., and Adler, A. 1976. The origin of chickpea Cicer arietinum L. Euphytica 25:211-217.

Lancashire, P., Van DenBoom, T., Langeluddeke, P., Stauss, R., Weber, E., and Witzenberger, A. 1991. A uniform decimal code for growth stages of crops and weeds. Ann. Appl. Biol. 119:561-601.

Li, H., Rodda, M., Gnanasambandam, A., Aftab, M., Redden, R., Hobson, K., Rosewarne, G., Materne, M., Kaur, S., and Slater, A. T. 2015. Breeding for biotic stress resistance in chickpea: Progress and prospects. Euphytica 204: 257-288.

Marks, C. F., and Proctor, J. R. 1974. The determination of normalising transformations for nematode count data from soil samples and of efficient sampling schemes. Nematologica 20:395-406.

Muñoz, N., Liu, A., Kan, L., Li, M.-W., and Lam, H.-M. 2017. Potential uses of wild germplasms of grain legumes for crop improvement. Int. J. Mol. Sci. 18:328.

O'Brien, P. C. 1982. A study on the host range of Pratylenchus thornei. Australas. Plant Pathol. 11:3-5.

O'Reilly, M. M., and Thompson, J. P. 1993. Open pot culture proved more convenient than carrot callus culture for producing Pratylenchus thornei inoculum for glasshouse experiments. Pages 5-9 in: Pratylenchus Workshop, Australas. Plant Pathol. Soc. Conf., Hobart.

Owen, K. J., Clewett, T. G., Bell, K. L., and Thompson, J. P. 2014. Wheat biomass and yield increased when populations of the root-lesion nematode Pratylenchus thornei were reduced through sequential rotation of partially resistant winter and summer crops. Crop Pasture Sci. 65:227-241.

Patterson, H., and Thompson, R. 1971. Recovery of inter-block information when block sizes are unequal. Biometrika 58:545-554.

Perez-Hidalgo, M. A., Guerra-Hernández, E., and García-Villanova, B. 1997. Dietary fibre in three raw legumes and processing effect on chick peas by an enzymatic-gravimetric method. J. Food Compos. Anal. 10:66-72.

Peters, B. G. 1952. Toxicity tests with vinegar eelworm. 1. Counting and culturing. Helminthology 26:97-110.

Pulse Australia. 2016. Best management guide, Chickpea production northern region. www.pulseaus.com.au/growing-pulses/bmp/chickpea/northernguide

Rao, L. S., Usha Rani, P., Deshmukh, P. S., Kumar, P. A., and Panguluri, S. K. 2007. RAPD and ISSR fingerprinting in cultivated chickpea (Cicer arietinum L.) and its wild progenitor Cicer reticulatum Ladizinsky. Genet. Resour. Crop Evol. 54:1235-1244.

R Core Team. 2018. R: A Language and Environment for Statistical Computing. R Foundation for Statistical Computing, Vienna, Austria. https:// www.R-project.org/

Reddy, M. V., and Singh, K. B. 1984. Evaluation of world collection of chickpea germplasm lines for resistance to Ascochyta blight. Plant Dis. 68: 900-901.

Reddy, M. V., and Singh, K. B. 1992. Registration of five chickpea germplasm lines resistant to Ascochyta blight. Crop Sci. 32:1079-1080.

Reen, R. A., Thompson, J. P., Clewett, T. G., Sheedy, J. G., and Bell, K. L. 2014. Yield response in chickpea cultivars and wheat following crop rotations affecting population densities of Pratylenchus thornei and arbuscular mycorrhizal fungi. Crop Pasture Sci. 65:428-441.

Robinson, H., Kelly, A., Fox, G., Franckowiak, J., Borrell, A., and Hickey, L. 2018. Root architectural traits and yield: Exploring the relationship in barley breeding trials. Euphytica 214:151. 
Rodda, M. S., Hobson, K. B., Forknall, C. R., Daniel, R. P., Fanning, J. P., Pounsett, D. D., Simpfendorfer, S., Moore, K. J., Owen, K. J., Sheedy, J. G., Thompson, J. P., Hollaway, G. J., and Slater, A. T. 2016. Highly heritable resistance to root-lesion nematode (Pratylenchus thornei) in Australian chickpea germplasm observed using an optimised glasshouse method and multi-environment trial analysis. Australas. Plant Pathol. 45:309-319.

Saeed, A., Hovsepyan, H., Darvishzadeh, R., Imtiaz, M., Panguluri, S. K., and Nazaryan, R. 2011. Genetic diversity of Iranian accessions, improved lines of chickpea (Cicer arietinum L.) and their wild relatives by using simple sequence repeats. Plant Mol. Biol. Rep. 29:848-858.

Sheedy, J. G., and Thompson, J. P. 2009. Resistance to the root-lesion nematode Pratylenchus thornei of Iranian landrace wheat. Australas. Plant Pathol. 38:478-489.

Singh, K. B., and Ocampo, B. 1997. Exploitation of wild Cicer species for yield improvement in chickpea. Theor. Appl. Genet. 95:418-423.

Singh, M., Kumar, K., Bisht, I. S., Dutta, M., Rana, M. K., Rana, J. C., Bansal, K. C., and Sarker, A. 2015. Exploitation of wild annual Cicer species for widening the gene pool of chickpea cultivars. Plant Breed. 134:186-192.

Singh, S., Gumber, R. K., Joshi, N., and Singh, K. 2005. Introgression from wild Cicer reticulatum to cultivated chickpea for productivity and disease resistance. Plant Breed. 124:477-480.

Smith, A. B., Cullis, B. R., and Thompson, R. 2001. Analysing variety by environment data using multiplicative mixed models and adjustments for spatial field trend. Biometrics 57:1138-1147.

Smýkal, P., Nelson, M. N., Berger, J. D., and Von Wettberg, E. J. B. 2018. The impact of genetic changes during crop domestication. Agronomy (Basel, Switzerland) 8:119.

Starr, J. L., Cook, R., and Bridge, J., eds. 2002. Pages 4-5 in: Plant Resistance to Parasitic Nematodes. CABI Publishing, Wallingford, U.K.

Sudupak, M., Akkaya, M., and Kence, A. 2002. Analysis of genetic relationships among perennial and annual Cicer species growing in Turkey using RAPD markers. Theor. Appl. Genet. 105:1220-1228.

Talip, M., Adak, A., Kahraman, A., Berger, J., Sari, D., Sari, H., Penmetsa, R. V., von Wettberg, E. J., Cook, D. R., and Toker, C. 2018. Agromorphological traits of Cicer reticulatum Ladizinsky in comparison to C. echinospermum P.H. Davis in terms of potential to improve cultivated chickpea (C. arietinum L.). Genet. Resour. Crop Evol. 65:951-962.

Tanno, K.-i., and Willcox, G. 2006. The origins of cultivation of Cicer arietinum L. and Vicia faba L.: Early finds from Tell el-Kerkh, north-west Syria, late 10th millennium b.p. Veg. Hist. Archaeobot. 15:197-204.

Thompson, J. P. 1990. Treatments to eliminate root-lesion nematode (Pratylenchus thornei Sher and Allen) from a vertisol. Nematologica 36:123-127.

Thompson, J. P. 2008. Resistance to root-lesion nematodes (Pratylenchus thornei and $P$. neglectus) in synthetic hexaploid wheats and their durum and Aegilops tauschii parents. Aust. J. Agric. 59:432-446.

Thompson, J. P., Brennan, P. S., Clewett, T. G., Sheedy, J. G., and Seymour, N. P. 1999. Progress in breeding wheat for tolerance and resistance to rootlesion nematode (Pratylenchus thornei). Australas. Plant Pathol. 28:45-52.

Thompson, J. P., Clewett, T. G., and O'Reilly, M. M. 2015a. Optimising initial population density, growth time and nitrogen nutrition for assessing resistance of wheat cultivars to root-lesion nematode (Pratylenchus thornei). Australas. Plant Pathol. 44:133-147.

Thompson, J. P., Clewett, T. G., and O'Reilly, M. M. 2015b. Temperature response of root-lesion nematode (Pratylenchus thornei) reproduction on wheat cultivars has implications for resistance screening and wheat production. Ann. Appl. Biol. 167:1-10.

Thompson, J. P., Clewett, T. G., Sheedy, J. G., Reen, R. A., O’Reilly, M. M., and Bell, K. L. 2010. Occurrence of root-lesion nematodes (Pratylenchus thornei and P. neglectus) and stunt nematode (Merlinius brevidens) in the northern grain region of Australia. Australas. Plant Pathol. 39:254-264.

Thompson, J. P., Greco, N., Eastwood, R., Sharma, S. B., and Scurrah, M. 2000. Integrated control of nematodes of cool-season food legumes. Pages 491-495 in: Linking Research and Marketing Opportunities for Pulses in the 21st Century. R. Knight, ed. Current Plant Science and Biotechnology in Agriculture, Vol. 34. Kluwer Academic Publishers, Dordrecht, The Netherlands.

Thompson, J. P., Reen, R. A., Clewett, T. G., Sheedy, J. G., Kelly, A. M., Gogel, B. J., and Knights, E. J. 2011. Hybridisation of Australian chickpea cultivars with wild Cicer spp. increases resistance to root-lesion nematodes (Pratylenchus thornei and P. neglectus). Australas. Plant Pathol. 40: 601-611.

Thompson, J. P., Rostad, H. E., and Whish, J. P. M. 2017. Survival of rootlesion nematodes (Pratylenchus thornei) after wheat growth in a vertisol is influenced by rate of progressive soil desiccation. Ann. Appl. Biol. 170: 78-88.

Toker, C., Canci, H., and Yildirim, T. 2007. Evaluation of perennial wild Cicer species for drought resistance. Genet. Resour. Crop Evol. 54:1781-1786.

Trudgill, D. L. 1991. Resistance to and tolerance of plant-parasitic nematodes in plants. Annu. Rev. Phytopathol. 29:167-192.

Varshney, R. K., Song, C., Saxena, R. K., Azam, S., Yu, S., Sharpe, A. G., Cannon, S., Baek, J., Rosen, B. D., Tar'an, B., Millan, T., Zhang, X., Ramsay, L. D., Iwata, A., Wang, Y., Nelson, W., Farmer, A. D., Gaur, P. M., Soderlund, C., Penmetsa, R. V., Xu, C., Bharti, A. K., He, W., Winter, P., Zhao, S., Hane, J. K., Carrasquilla-Garcia, N., Condie, J. A., Upadhyaya, H. D., Luo, M. C., Thudi, M., Gowdar, C. L. L., Singh, N. P., Lichtenzveig, J., Gali, K. K., Rubio, J., Nadarajan, N., Dolozel, J., Bansal, C., Xu, X., Edwards, D., Zhang, G., Kahl, G., Gil, J., Singh, K. B., Datta, S. K., Jackson, S. A., Wang, J., and Cook, D. R. 2013. Draft genome sequence of chickpea (Cicer arietinum) provides a resource for trait improvement. Nat. Biotechnol. 31:240-246.

Von Wettberg, E. J. B., Chang, P. L., Başdemir, F., Carrasquila-Garcia, N., Korbu, L. B., Moenga, S. M., Bedada, G., Greenlon, A., Moriuchi, K. S., Singh, V., Cordeiro, M. A., Noujdina, N. V., Dinegde, K. N., Shah Sani, S. G. A., Getahun, T., Vance, L., Bergmann, E., Lindsay, D., Mamo, B. E., Warschefsky, E. J., Dacosta-Calheiros, E., Marques, E., Yilmaz, M. A., Cakmak, A., Rose, J., Migneault, A., Krieg, C. P., Saylak, S., Temel, H., Friesen, M. L., Siler, E., Akhmetov, Z., Ozcelik, H., Kholova, J., Can, C., Gaur, P., Yildirim, M., Sharma, H., Vadez, V., Tesfaye, K., Woldemedhin, A. F., Tar'an, B., Aydogan, A., Bukun, B., Penmetsa, R. V., Berger, J., Kahraman, A., Nuzhdin, S. V., and Cook, D. R. 2018. Ecology and genomics of an important crop wild relative as a prelude to agricultural innovation. Nat. Commun. 9:Article 649.

Whish, J. P. M., Thompson, J. P., Clewett, T. G., Wood, J., and Rostad, H. E. 2017. Predicting the slow decline of root lesion nematode (Pratylenchus thornei) during host-free fallows to improve farm management decisions. Eur. J. Agron. 91:44-53.

Whitehead, A., and Hemming, J. 1965. A comparison of some quantitative methods of extracting small vermiform nematodes from soil. Ann. Appl. Biol. 55:25-38.

Zadoks, C. T., Chang, T. T., and Konzak, C. F. 1974. A decimal code for the growth stages of cereals. Weed Res. 14:415-421.

Zwart, R. S., Thompson, J. P., and Godwin, I. D. 2005. Identification of quantitative trait loci for resistance to two species of root-lesion nematode (Pratylenchus thornei and P. neglectus) in wheat. Aust. J. Agric. Res. 56: 345-352. 